\title{
Social Service Delivery in Southwestern Nigeria: Local Governments Perspective
}

\author{
Odewale, Ayotunde David (Ph.D) \\ Department of Local Government Studies, Faculty of Administration, Obafemi \\ Awolowo University, Ile-Ife, Nigeria \\ Badejo, B. T (Ph.D) \\ Department of Local Government Studies, Faculty of Administration, Obafemi \\ Awolowo University, Ile-Ife, Nigeria
}

Received: Nov. 22, 2018 Accepted: Dec. 10, 2018 Online published: Dec., 26, 2018

doi:10.5296/jpag.v8i4.14131

URL: https://doi.org/10.5296/jpag.v8i4.14131

\begin{abstract}
This paper assesses the impact of local government on social service delivery in south-western Nigeria in tandem with their full constitutional responsibility particularly on primary education and road constructions. The related concepts were review. The study utilized both primary and secondary data. Primary data were collected through questionnaire administration and in-depth interviews. The study revealed that local government has a significant impact on social service delivery in Southwestern Nigeria $(r=0.438, p<0.05)$. The paper highlighted some recommendations and concluded that local government had performed considerably well in delivery of social service to the populace in their concurrent responsibility with the state government, but relatively low in their mandatory functions.
\end{abstract}

Keywords: social service delivery, good governance, local government, southwestern and Nigeria

\section{Introduction}

The primary function of any government is to provide essential services and to ensure the security of lives and property. The essence for the creation of Local Government anywhere in the world stems from the need to facilitate development at the grassroots. Thomson (2004) opines that the failure of government is a failure of service delivery. Improving service delivery is synonymous with improving the relationship between citizens and government. Certainly, there is no gainsaying, Local Government in Nigeria has passed through several phases and has been shaped by several factors. 
Historically, local governments have always been assigned different functions to perform. The Native Authority system was committed to the maintenance of law and order, and to consolidate colonial hegemony during colonisation. However, with the emergence of independence, emphasis shifted from law enforcement to the provision of social services (Adeyemo, 2005). The era of pre-colonialism, colonialism, independence, and post-independence up till the fourth republic, which started on $29^{\text {th }}$ of May 1999 witnessed a paradigm shift from maintenance of law and order to the provision of social service with constitutional jurisdictions and powers.

The 1999 Constitution of the Federal Republic of Nigeria provides for two sets of functions for Local Government i.e exclusive and concurrent functions. Adeyeye (2016) elucidates further that three sets of Local Government functions were recognized, namely the Exclusive (Mandatory), Concurrent and Permissive (additional) functions. The exclusive functions are functions listed in the Fourth Schedule part A while concurrent functions in part B include provision and maintenance of primary, adult and vocational education, health services and agricultural extension services, industrial and commercial services and other functions that are prescribed by the House of Assembly.

Local governments embark on concurrent functions in conjunction with State and Federal Governments but most, especially with the State Government. The permissive functions are normally not listed in statutes but are assigned by the appropriate legislative body in the intergovernmental context (Adeyeye, 2016). The constitutional responsibilities of local government in discharging the expected social service to the populace cut across both mandatory and concurrent functions particularly with the state government.

There are divergences of opinion about the success and failure of local government in Nigeria, especially in the delivery of social services that are needed at the grassroots level as stipulated in the Constitution and other statutes. Local government has also become the subject of debate across the country on how well they have been able to perform their constitutional mandate by rendering cutting-edge services that will foster socio-economic development at the grassroots level particularly since 1999. Thus, existing studies have little or no information on the efficacy of local government and social service delivery in tandem with their full constitutional roles i.e both the exclusive and concurrent functions so as to juxtapose the funds accrued to them. Local governments have been seen in isolation, especially on the concurrent functions. Hence, there is a need for this study to assess local government on social service delivery between 1999 and 2015 in Southwestern Nigeria as a reference point. The paper is organized in these sections. Following the introductory section, the second section provides a conceptual clarification, the third section talks about methodology, follow by findings, recommendations and conclusion.

\section{Conceptual Clarification}

\subsection{Social Service Delivery}

Social services cover a wide variety of different activities. Titmus (1968) views social services as "those services that are concerned with different types of moral transactions 
embodying the notion of gift-exchange which have developed in modern societies in institutional forms to bring about and maintain social and community relations". Similarly, Boulding (1962) posits that social services arise from social policy; and that "social policy deal with unilateral transfers that are justified (outside the fringes of the free market mechanism) by some kind of appeal to a status, legitimacy, identity or community." Olewe and Anga (1994) opine that social service is a wide concept that embraces the improvement of the social status of the individual and society in general. It necessitates, in reality and not deceitful, the provision of such services as education, health, roads, housing, potable water, and electricity. It seeks reduction in poverty, improvement of women and workers (SSC, 2011). Geol (1981) states that "social service is a process of bringing social change and the implementation of social policy decisions for the total welfare of the community". Social services encompass all techniques, acts and considerations in transforming social policy into a reality.

Nnamani and Chilaka (2012) assert that social service is a set of a programme aimed at achieving some objectives. It relates to the social system in the goals of social policies. In the process of achieving these objectives, social policies are expected to be formulated and these also are directed towards making some changes in the society so as to improve the living conditions of the people. The programmes such as free education, healthcare, housing and child protection are services provided by the government or its agents for the wellbeing of persons or the community at large.

The delivery of social services at the local government level is aimed at moving the standard of living of the populace to the next level (Angahar, 2013). Some of the social services that are expected from local government to deliver to the populace include education, health, roads, housing, rural electricity, waste disposal services, transport, and so on (Adeyemi, 2013; Agba, Akwara \& Idu, 2013).

Nwoba (2015) also sees social services as services that are provided by the government or by non-governmental agencies, which are official to individuals, groups or communities in order to cope with social issues and to enhance the wellbeing of the citizens, individually and collectively, and are justified outside the free-market mechanism so as to encourage integration and discourage alienation among the members of society. Unlike the other public services, which are provided by the different levels of government, because the market economy cannot (would not or cannot efficiently) provide them, social services are provided to strengthen and maintain community relations. Social services are "service dedicated to enhancing people's economic and social wellbeing by helping them to attain more stable, healthy, self-sufficient and fulfilling lives" (New Zealand Productivity Commission (NZPC), 2015).

\subsection{Good Governance}

Governance is a multi-dimensional concept which encompasses both formal and informal institutions in exercising their authority and the management of the resource of a state. The quality of governance can be measured by the quality of life the citizens enjoyed. Arbitrarily, Governance is defined as the government's ability to make and enforce rules and to deliver 
services, regardless of the type of government in operation. Coleman (1965) defines governance as "the process of decision making and the process by which those decisions are implemented [or not implemented]".

Chazan (1992) asserts that governance "is the capacity to establish and sustain workable relations between individual actors in order to promote collective goals". This definition also established the relationship between actors, which include the government and the citizens so as to promote collective goals which must include the expectation of the citizen from the government and vice versa. Galadima (1998) also defines governance as "a process of managing and organising legitimate power structures given by the people to maintain law and order, ensure rule of law, protect fundamental human rights, provide for the basic needs and wellbeing of the populace, and the pursuit of their happiness". This definition explicates that the activities of government should encompass equity and justice, and in the long run, basic needs of the citizens should be pursued and whose outcome will bring happiness to the majority of the populace.

Yaqub and Abubakar (2005) also opine that governance is the "totality of the process of constituting a government as well as administering a political community". This involves the activities of stakeholders of government and the result to the society at large. Similarly, Ninalowo (2005) adds that "governance is the totality of executive or administrative functions of the state, with a view to fulfilling terms of constitutional obligations or social contract to the citizenry". Natufe (2006) equally defines governance as "the process by which government manages the resources of society so as to address the issues of political challenges and socio-economic in the polity". In a similar vein, Fukuyama (2013) argues that governance is "the ability of government to make and enforce rules and regulations that would foster service delivery, regardless of whether that government is democratic or not". This means that the priority of government to the citizenry is to provide services to the citizens in an efficient and effective manner regardless of the system of government, be it democratic, military or otherwise. Governance is that quality of the relationship between the government and the populace whom it protects and serves.

Good governance is a combination of two words, that is "good" and "governance". "Good" on one hand means what is satisfactory in quality or degree, right, proper, friendly, honorable, beneficent, worthy, reliable, responsible and dependable. "Governance" on the other hand is a method or system of government. Conable (1997) asserts that "good governance encompasses the exercise of power or authority, economic, political, administrative or otherwise to manage a country's resources through which the citizens articulate their interests, harmonises their differences and exercise their legal rights".

The United Nations Development Programme, UNDP (1997) stated that "good governance can be seen as the exercise of political, economic and administrative power to manage a country's affairs at all levels". It further explained that good governance has three dimensions: political, economic and administrative. Political governance involves the process of decision-making to policy formulation. Economic governance includes the process of decision-making that affects the economic activities of a country and its relationships with 
other economies. It has major implications for equity, poverty and quality of life. Administrative governance is the system of policy implementation. The political class decides and formulates policy while the administrative class implements the policy. Encompassing the three, good governance can be defined as the structures and processes that guide the relationship between political and socio-economic class.

Downer (2000) also asserts that "good governance is the process whereby public institutions conduct public affairs, manage public resources and guarantee the realization of human rights". He further explains that one of the ways to measure good governance is the rate at which the promise of government is delivered to the citizens, especially in relating to their rights socially, economically, culturally and politically. Hope (2005) view, good governance is a situation where government responsibility is discharged in an effective, accountable and transparent manner. Good governance involves accountability, participation, and transparency, among other things. It promotes effectiveness, equitableness and rule of law. Good governance ensures a broad consensus politically, economically and socially to enshrine the choice of the masses in decision-making over the allocation of resources (Madhav, 2007).

Odock (2006) sees good governance as "a system that has respect for good leadership, accountability, rule of law, due process and transparency in the operations of government". Onifade (2011) poses a critical question as to whether it is possible to have good governance without good leadership. A good leadership would culminate in good governance, and good leadership could also be measured by the way and manner the principles of good governance are being adhered to. Adeosun (2012) also refers to good governance as proper management of a country's resources in a manner that is accountable, transparent, equitable and responsive to the aspirations of the populace.

From the foregoing, it could be understood that governance is a relationship between rulers and the ruled, the state and the society, the governors and the governed. While good governance could be the relationship between the ruler and the ruled, with the instrumentality of the state aid based on the broad consensus of the society and the consideration of the poor when making decision over the allocation of resources.

\subsection{Local Government}

It is pertinent to state that there is no single definition for the concept of Local Government. Many scholars define Local Government differently due to various perspectives on the actual roles and functions of Local Government which differ from one nation to another and from one environment to another.

United Nations Office for Public Administration defines Local Government as "a political subdivision of a nation or (in a Federal system) state, which is constituted by law and has substantial control of local affairs, including the powers to impose taxes or to exact labor for prescribed purposes. The [such] governing body is elected or otherwise locally selected". Though Local Government in Nigeria is a political subdivision of the Federal and State Governments, and is constituted by law, the "substantial control of local affairs" expected from the Local Government is missing in Nigerian context. The state government has wiped 
away that substantial control of local affairs and local government has remained an appendage of state government.

Robson (1949) sees local government as "a territorial non-sovereign community possessing the legal rights and necessary organisation to regulate its own affairs". There is territory, legal backing and ability to deal with the affairs of local populace. There is no doubt that each Local Government in Nigeria is distinctly mapped out territorially, yet we cannot dispute the problem of boundary adjustment here and there in the country. So also, Local Government is still subject to the control and supervision of other tiers of government

Maddick (1963) sees Local Government as a sub-unit of government which is controlled by the local council and derived it authority from the central government, so as to pass ordinances and laws with local application to levy taxes or exact labour within the limit specified by the central government and varied centrally decided policy. It is constitutionally recognised that, local government is a distinct tier of government in Nigeria and at the same time, but every state government of the Federation still needs to empower and guarantee the structure, finance, and composition of local governments in their various states. So also, the policy emanating from the central government could be implemented locally through the instrumentality of government at the local level.

\section{Theoretical Framework}

Structural Functionalism Theory was adopted as theoretical framework for this study. The prominent exponents of Structural-Functional theory in political science are Gabriel Almond, William C. Mitchell and David Apter (Nyewusira, 2011). The theory framework that sees society as a complex system whose parts work together to promote solidarity and stability. The theory revolves around the concepts of 'structure' and 'functions'. Almond and Powell (1966) opine that structure connotes 'the observable activities which make up a system' while functions deal with the consequences involving objectives as well as processes of the patterns of action. Functions deal with the consequences of a pattern of action that involve the processes and achievement of its objectives, while structures refer to those arrangements, which perform functions or roles (Ake,1975; Das \& Choudhury, 2002).

This approach addresses both the structure and the functions as a complete entity that need to solidify the society. Functionalism sees society in its full form and capacity to perform its constituent functions; namely traditions, customs, norms, and institutions. Herbert Spencer makes a common analogy of this approach by presenting these parts of society as "organs" that work for proper functioning of the whole "body". The approach becomes clearer with a concise explanation of functionalism and structuralism on the fact that they are very closely related paradigm despite their mutuality. Anikpo (2006) sees functionalism as 'a teleological posture' with significance component that 'keep the society in equilibrium'. Das \& Choudhury (2002) present the following as the basic assumptions of the structural-functional theory;

i. All systems have structures which can be identified and that the elements of these structures perform certain functions within the system, which have meaning only in terms of the system. 
They are also dependent on each other for their actions.

ii. The society is a single interconnected system, each element performing a specific function. The interaction among the component parts is necessary for the maintenance of the equilibrium.

iii. The different parts of society are inter-related, and tensions are resolved with mutual help.

iv. The broad aims or principles underlying a social structure can be identified.

The approach looks at the society through a macro-level orientation which is a broad focus on the social structures that shape society as a whole and believes that society has evolved like organisms. The analogy of Spencer sees society as an organism that needs the proper functioning of all its parts. He sees the human body as the structural parts like skeletons, muscles, and internal organs that function independently for the entire organism to survive, and dysfunction of any part of these structural parts may lead to the collapse of the whole organism. He observes that proper working of social structure work together to preserve the society.

\section{Methodology}

The study utilised both primary and secondary data. Primary data were collected through questionnaire and in-depth interviews. Multi-stage sampling technique was used to select eighteen Local Government Areas from Southwestern Nigeria. The study population was 3,158 consisting of senior officers on grade levels 07-16 in Works (478); Community Development and Information (CDI) (380); and Local Government Education Authority (LGEA) (144). Also, selected for the administration of questionnaire are Traditional Rulers (50); executives of Market Women Associations (MWA) (90); executives of Nigeria Union of Local Government Employee (NULGE) (126); executives of National Union of Road Transport Workers (NURTW) (54); executives of Nigeria Union of Teachers (NUT) (144); executives of Parent Teachers Association (PTA)/ Community Based School Management Committee (CBSMC) (1134) and executives of Community Development Associations (CDAs) (558). The sample size was 632, representing $20 \%$ of the total study population. In addition, interviews were conducted for 42 selected Stakeholders to elicit information in the three selected States. Secondary data were obtained from academic journals, official document and government publications. Data collected were analysed using frequency, percentage, mean value, standard deviation and correlation co-efficient. The scope of social service delivery in the context of this study is confined and limited to the primary education delivery and construction and maintenance of roads, which are parts of the constitutional function of the Local Government in Nigeria. 
Table 1. Impact of Local Government on Social Service Delivery in South-western Nigeria between 1999 and 2015

\begin{tabular}{|c|c|c|c|c|c|c|c|c|c|}
\hline & \multirow[b]{2}{*}{ Assertions } & \multirow{2}{*}{\begin{tabular}{|c|}
$\begin{array}{c}\text { Strongly } \\
\text { Agree }\end{array}$ \\
$\mathrm{f}$ \\
$(\%)$ \\
\end{tabular}} & \multirow{2}{*}{$\begin{array}{c}\text { Agree } \\
\mathrm{f} \\
(\%) \\
\end{array}$} & \multirow{2}{*}{\begin{tabular}{|c|} 
Undecided \\
$\mathrm{f}$ \\
$(\%)$ \\
\end{tabular}} & \multirow{2}{*}{\begin{tabular}{|c|} 
Disagree \\
$\mathrm{f}$ \\
$(\%)$ \\
\end{tabular}} & \multirow{2}{*}{$\begin{array}{c}\text { Strongly } \\
\text { Disagree } \\
\mathrm{f} \\
(\%) \\
\end{array}$} & \multirow{2}{*}{\begin{tabular}{c|}
$\begin{array}{c}\text { No } \\
\text { Response }\end{array}$ \\
$\mathrm{f}$ \\
$(\%)$ \\
\end{tabular}} & \multicolumn{2}{|c|}{$\begin{array}{r}\text { Descriptive } \\
\text { Statistics }\end{array}$} \\
\hline $\mathrm{S} / \mathrm{N}$ & & & & & & & & $\begin{array}{l}\text { Mean } \\
\text { Value }\end{array}$ & $\begin{array}{c}\text { Standard } \\
\text { Deviation }\end{array}$ \\
\hline & $\begin{array}{l}\text { Construction of schools } \\
\text { (primary education) has made } \\
\text { the inclusive education to be } \\
\text { achieved in this local } \\
\text { Government especially between } \\
1999 \text { and 2015. }\end{array}$ & $\begin{array}{c}155 \\
(27.2)\end{array}$ & $\begin{array}{c}255 \\
(44.7)\end{array}$ & $\begin{array}{c}50 \\
(8.8)\end{array}$ & $\begin{array}{c}69 \\
(12.1)\end{array}$ & $\begin{array}{c}23 \\
(4.0)\end{array}$ & $\begin{array}{c}18 \\
(3.2)\end{array}$ & 3.28 & 1.454 \\
\hline & $\begin{array}{l}\text { The ability of pupils in primary } \\
\text { schools to communicate } \\
\text { effectively and inculcate } \\
\text { permanent literacy has been } \\
\text { achieved in this local } \\
\text { government between } 1999 \text { and } \\
2015\end{array}$ & $\begin{array}{c}85 \\
(14.9)\end{array}$ & $\begin{array}{c}265 \\
(46.5)\end{array}$ & $\begin{array}{l}44 \\
(7.7)\end{array}$ & $\begin{array}{c}135 \\
(23.7)\end{array}$ & $\begin{array}{c}31 \\
(5.4)\end{array}$ & $\begin{array}{c}10 \\
(1.8)\end{array}$ & 3.36 & 1.381 \\
\hline & $\begin{array}{l}\text { The basic knowledge and } \\
\text { preparatory ground for further } \\
\text { education which are expected } \\
\text { from primary education has } \\
\text { been achieved in this Local } \\
\text { government especially between } \\
1999 \text { and } 2015\end{array}$ & $\begin{array}{c}90 \\
(15.8)\end{array}$ & $\begin{array}{c}258 \\
(45.3)\end{array}$ & $\begin{array}{c}90 \\
(15.8)\end{array}$ & $\begin{array}{c}99 \\
(17.4)\end{array}$ & $\begin{array}{c}21 \\
(3.7)\end{array}$ & $\begin{array}{c}12 \\
(2.1)\end{array}$ & 3.35 & 1.397 \\
\hline & $\begin{array}{l}\text { The activities of the local } \\
\text { government in delivering of } \\
\text { primary education has not } \\
\text { instilled social, moral norms } \\
\text { and values in the students }\end{array}$ & $\begin{array}{c}57 \\
(10.0)\end{array}$ & $\begin{array}{c}188 \\
(33.0)\end{array}$ & $\begin{array}{c}70 \\
(12.3)\end{array}$ & $\begin{array}{c}198 \\
(34.7)\end{array}$ & $\begin{array}{c}44 \\
(7.7)\end{array}$ & $\begin{array}{c}13 \\
(2.3)\end{array}$ & 2.94 & 1.696 \\
\hline & $\begin{array}{l}\text { Primary education has been a } \\
\text { fundamental service to be made } \\
\text { accessible to every citizen in } \\
\text { this Local government. }\end{array}$ & $\begin{array}{c}214 \\
(37.5)\end{array}$ & $\begin{array}{c}267 \\
(46.8)\end{array}$ & $\begin{array}{l}38 \\
(6.7)\end{array}$ & $\begin{array}{c}28 \\
(4.9)\end{array}$ & $\begin{array}{c}6 \\
(1.1)\end{array}$ & $\begin{array}{c}17 \\
(3.0)\end{array}$ & 3.69 & 1.334 \\
\hline & $\begin{array}{l}\text { Establishment and maintenance } \\
\text { of recreation facilities } \\
\text { (playgrounds, parks, open space } \\
\text { etc) for school pupils have no } \\
\text { effect on their socialization } \\
\text { process }\end{array}$ & $\begin{array}{c}84 \\
(14.7)\end{array}$ & $\begin{array}{c}138 \\
(24.2)\end{array}$ & $\begin{array}{c}49 \\
(8.6)\end{array}$ & $\begin{array}{c}197 \\
(34.6)\end{array}$ & $\begin{array}{c}86 \\
(15.1)\end{array}$ & $\begin{array}{c}16 \\
(2.8)\end{array}$ & 3.37 & 1.431 \\
\hline & $\begin{array}{l}\text { Construction and Maintenance } \\
\text { of Libraries has not enhanced } \\
\text { academic development among } \\
\text { the school pupils }\end{array}$ & $\begin{array}{c}127 \\
(22.3)\end{array}$ & $\begin{array}{c}156 \\
(27.4)\end{array}$ & $\begin{array}{c}64 \\
(11.2)\end{array}$ & $\begin{array}{c}110 \\
(19.3)\end{array}$ & $\begin{array}{c}82 \\
(14.4)\end{array}$ & $\begin{array}{c}31 \\
(5.4)\end{array}$ & 3.04 & 1.523 \\
\hline & $\begin{array}{l}\text { Construction and maintenance } \\
\text { of Roads have increased the } \\
\text { flow of goods and services in } \\
\text { this local government }\end{array}$ & $\begin{array}{l}142 \\
(24.9)\end{array}$ & $\begin{array}{c}187 \\
(32.8)\end{array}$ & $\begin{array}{c}27 \\
(4.7)\end{array}$ & $\begin{array}{c}142 \\
(24.9)\end{array}$ & $\begin{array}{c}58 \\
(10.2)\end{array}$ & $\begin{array}{c}14 \\
(2.5)\end{array}$ & 3.18 & 1.573 \\
\hline & $\begin{array}{l}\text { The activities of Local } \\
\text { government on the construction } \\
\text { and maintenance of Drainages } \\
\text { have not been encouraging }\end{array}$ & $\begin{array}{c}122 \\
(21.4)\end{array}$ & $\begin{array}{c}213 \\
(37.4)\end{array}$ & $\begin{array}{c}45 \\
(7.9)\end{array}$ & $\begin{array}{c}104 \\
(18.2)\end{array}$ & $\begin{array}{c}70 \\
(12.3)\end{array}$ & $\begin{array}{c}16 \\
(2.8)\end{array}$ & 3.01 & 1.611 \\
\hline
\end{tabular}




\begin{tabular}{|c|c|c|c|c|c|c|c|c|c|}
\hline & $\begin{array}{l}\text { Request for construction of } \\
\text { bridges by the populace has } \\
\text { been catered for by local } \\
\text { government }\end{array}$ & $\begin{array}{c}62 \\
(10.9)\end{array}$ & $\begin{array}{c}137 \\
(24.0)\end{array}$ & $\begin{array}{c}61 \\
(10.7)\end{array}$ & $\begin{array}{c}200 \\
(35.1)\end{array}$ & $\begin{array}{c}91 \\
(16.0)\end{array}$ & $\begin{array}{c}19 \\
(3.3)\end{array}$ & 3.39 & 1.433 \\
\hline xi. & $\begin{array}{l}\text { There are enough Motor parks } \\
\text { that encourage the flow of } \\
\text { goods and services to another } \\
\text { part of the country }\end{array}$ & $\begin{array}{c}97 \\
(17.0)\end{array}$ & $\begin{array}{c}197 \\
(34.6)\end{array}$ & $\begin{array}{c}46 \\
(8.1)\end{array}$ & $\begin{array}{c}129 \\
(22.6)\end{array}$ & $\begin{array}{c}85 \\
(14.9)\end{array}$ & $\begin{array}{c}16 \\
(2.8)\end{array}$ & 3.20 & 1.260 \\
\hline xii. & $\begin{array}{l}\text { Grading of roads, especially in } \\
\text { core rural areas, has increased } \\
\text { the flow of farm products from } \\
\text { farm settlements to the cities }\end{array}$ & $\begin{array}{c}120 \\
(21.1)\end{array}$ & $\begin{array}{c}209 \\
(36.7)\end{array}$ & $\begin{array}{c}20 \\
(3.5)\end{array}$ & $\begin{array}{c}131 \\
(23.0)\end{array}$ & $\begin{array}{c}74 \\
(13.0)\end{array}$ & $\begin{array}{c}16 \\
(2.8)\end{array}$ & 3.21 & 1.257 \\
\hline xiii. & $\begin{array}{l}\text { Construction and maintenance } \\
\text { of Street lightings have a } \\
\text { positive impact on social } \\
\text { development in this Local } \\
\text { government }\end{array}$ & $\begin{array}{c}105 \\
(18.4)\end{array}$ & $\begin{array}{c}139 \\
(24.4)\end{array}$ & $\begin{array}{c}42 \\
(7.4)\end{array}$ & $\begin{array}{c}165 \\
(28.9)\end{array}$ & $\begin{array}{c}105 \\
(18.4)\end{array}$ & $\begin{array}{c}14 \\
(2.5)\end{array}$ & 2.81 & 1.699 \\
\hline xiv. & $\begin{array}{l}\text { The inability to render quality } \\
\text { service is evident by the number } \\
\text { of poor quality of services } \\
\text { especially in the area of primary } \\
\text { education and road construction } \\
\text { between } 1999 \text { and } 2015\end{array}$ & $\begin{array}{c}131 \\
(23.0)\end{array}$ & $\begin{array}{c}252 \\
(44.2)\end{array}$ & $\begin{array}{c}54 \\
(9.5)\end{array}$ & $\begin{array}{c}76 \\
(13.3)\end{array}$ & $\begin{array}{c}41 \\
(7.2)\end{array}$ & $\begin{array}{c}16 \\
(2.8)\end{array}$ & 3.61 & 1.192 \\
\hline
\end{tabular}

Source: Field Survey, 2018

\section{Test of Hypothesis}

This section deals with the analysis/interpretation of the hypothesis of this study. The statistical tool used in the analysis of the data is Spearman's correlation coefficient. The level of significance used in the analysis is $5 \%$ (i.e. 0.05 ).

Table 2. Correlation analysis between Impact of Local Government on Social Service delivery in Southwestern Nigeria between 1995 and 2015

\begin{tabular}{l|c|c|c|c}
\hline \multicolumn{1}{c|}{ Hypothesis } & \multicolumn{3}{|c}{} \\
\hline Local government has & Correlatio & Df & p-value & $\mathrm{N}$ \\
no significant impact & $\mathrm{n}$ & & & \\
on social service & coefficient & & & \\
delivery & $(\mathrm{r})$ & & & \\
Southwestern Nigeria & +0.438 & 1 & 0.000 & 570 \\
\cline { 2 - 5 } & & & & \\
\hline
\end{tabular}

Source: Field Survey, 2018

The Table 2 above presents the correlation analysis between local government and social service delivery in selected local government area within Southwestern Nigeria. The Spearman's correlation coefficient was positive $(+0.438)$, which is significant at $p<0.05$. The positive coefficient indicated that there is forty $(43 \%)$ positive relationship between the impactful roles of local government and social service delivery in Southwestern Nigeria. 
Since probability value (0.000) is lesser than alpha level (0.05), the study, therefore, rejected the null hypothesis and concluded that local government has a significant impact on social service delivery in Southwestern Nigeria $(r=0.438, p<0.05)$.

The spearman coefficient, therefore, implies that two-fifths of the changes occurring on the delivery of social services at the local level in Southwestern Nigeria are associated with the impactful roles of local government. The positive relationship also showed that the better roles of local government, the better the delivery of social services in selected local government Areas within Southwestern Nigeria.

\section{Findings of the Study}

This section assesses the impact of social service delivery by the local government on the populace in Southwestern Nigeria as the study area between 1999 and 2015. In an attempt to achieve this objective, respondents were asked to either agree or disagree with the specific roles/activities of the local government that are geared towards the provision of social service delivery, especially in the areas of primary education and road construction in the study areas within the period under study. The Table 1 revealed the frequency and percentage distribution of respondents on each of the investigative assertions set out to measure the impact of local government on social service delivery; and its values/responses were organised using Likert scale of measurements such as: Strongly Agree , Agree, Undecided, Disagree and Strongly Disagree. In addition, the mean value $\overline{(\chi)}$ summarises the strength of the respondents for each of the assertions set out to achieve this objective, using a decision rule as thus: where $\bar{\chi}>$ $2.5)$, more respondents agreed, and where $\overline{(\chi}<2.5)$, more respondents disagreed.

As shown in Table 4.3a, $155(27.2 \%)$ strongly agreed and 255 (44.7\%) agreed that Construction of schools (primary education) has made the inclusive education to be achieved in the local Government, especially between 1999 and 2015. There was still observable disagreement level of less than $10 \%$ to this assertion. Meanwhile, an aggregate of $81.9 \%$ respondents appear affirmative to this assertion $\bar{\chi}=3.28, \mathrm{SD}=1.454)$. This is rather an indication that constructions of primary schools have a significant impact on inclusive education, which comprises one of the social services to be delivered by local government in Nigeria.

To assess local government impact, it was stated that the ability of pupils in primary schools to communicate effectively and imbibe permanent literacy has been achieved in the local government between 1999 and 2015. It was notable in their reactions that an approximate of $61.4 \%$ respondents acknowledged the assertion, aggregating 85 (14.9\%) who strongly agreed and $265(46.5 \%)$ who ordinarily agreed. Meanwhile, about 10 representing $1.8 \%$ of the respondents made no response; and $166(29.1 \%)$ of the respondents fell in the disagreement category with this assertion $\bar{\chi}=3.36, \mathrm{SD}=1.381)$. This is an indication that appreciable level of literacy has been evident among primary schools pupils especially on communication, as entrenched through the concerted efforts of local government in the study area.

In addition, respondents were asked to either agree or disagree to the statement on whether the basic knowledge and preparatory ground for further education which are expected from 
primary education have been achieved in local government, especially between 1999 and 2015. In their responses, $90(15.8 \%)$ of the respondents strongly agreed to this assertion; and $258(45.3 \%)$ of the respondents ordinarily agreed. This becomes statistically verified by the $\overline{(} \chi=3.35, \mathrm{SD}=1.397)$ which is above mid-point 3.0. Meanwhile, $99(17.4 \%)$ of the respondents disagreed with this assertion; and 21 (3.7\%) of the respondents strongly disagreed. This is an indication that institutional efforts are, most often, being stressed by the local government towards providing basic knowledge for higher levels of education.

Also, $57(10 \%)$ of the respondents strongly agreed; and 188 (33\%) also neutrally agreed. However, 44 (7.7\%) strongly disagreed and 198 (34.7\%) of the respondents disagreed to the statement that the activities of local government in delivering of primary education has not instilled social, moral norms and values in the students. Though, about 70 (12.3\%) of the respondents remain indifferent to the assertion; while $13(2.3 \%)$ of the respondents did not react to this assertion. In this respect, this result showed mixed level on both agreements $43 \%$ and disagreement $42.4 \%$ of the respondents respectively. This implies that local government has, but not to a remarkable extent, impact on the inculcation of social norms and value system on primary school pupils $\overline{(} \chi=2.94, \mathrm{SD}=1.696)$.

This study acknowledged the fact that the primary education has been a fundamental service to be made accessible to every citizen in Local government $\bar{\chi}=3.69, \mathrm{SD}=1.334)$. This finding was revealed by $214(37.5 \%)$ and 267 (46.8\%) of the respondents strongly agreed and agreed respectively with the assumption that primary education is a cardinal indicator of the social service progression significance in the selected Local Government Areas within Southwestern Nigeria. Nevertheless, only about $6 \%$ of the respondents denied this assertion. This reveals that the primary education has not been totally impactful and accessible by citizens within the selected Local Government Areas in Southwestern Nigeria.

It was however asserted that the establishment and maintenance of recreation facilities (playgrounds, parks, open space, etc) for school pupils have no effect on their socialisation process. Responding to this assertion, this assumption was refuted by 197 representing $34.6 \%$ of the respondents and $86(15.1 \%)$ of the respondents who disagreed with this negative notion. Meanwhile, an approximate of $39 \%$ respondents fell in agreement with the assumption $\bar{\chi}=$ 3.37 , SD $=1.431$ ). This implies that establishment and maintenance of recreational facilities have, though with few available ones, an observable impact on social service delivery at the local level.

As shown in Table 1, about 127 (22.3\%) of the respondents strongly agreed and $156(27.4 \%)$ of the respondents ordinarily agreed to the assertion that construction and maintenance of Libraries have not enhanced academic development among the school pupils. Meanwhile, about $31(5.4 \%)$ of the respondents did not react to this assertion. However, $82(14.4 \%)$ of the respondents strongly disagreed; and $110(19.3 \%)$ of the respondents disagreed with the assertion. From this data distribution, an approximate of $50 \%$ respondents fell in agreement with this assertion. The agreement level was further verified by the $\bar{\chi}=3.04, \mathrm{SD}=1.523$ ) which is below 3.0 mid-point. By implication, both construction and maintenance of libraries have not engendered resultant impact on the academic development of primary school pupils, 
possibly due to the infrequent usage of the libraries by the pupils.

It was also asserted for respondents to react to whether the construction and maintenance of Roads have increased the flow of goods and services in this local government. In their reactions, an approximate of $60 \%$ respondents maintained an agreement position with the assertion. However, $35.1 \%$ of the respondent discredited this assertion. While, just $4.7 \%$ of the respondents were undecided; and $2.5 \%$ of the respondents did not react $\bar{\chi}=3.18, \mathrm{SD}=$ 1.573). This is an indication that more statistical weight is pulled towards an agreement to the assertion.

It was opined that the activities of local government on the construction and maintenance of drainages have not been encouraging. Reacting to this opinion, there are varied reactions: 16 $(2.8 \%)$ of the respondents did not respond; 45 (7.9\%) of the respondents undecided; 70 $(12.3 \%)$ of the respondents strongly disagreed; $104(18.2 \%)$ of the respondents neutrally disagreed; $122(21.4 \%)$ of the respondents agreed to the assertion; and to $37.4 \%$ of the respondents strongly agreed to the assertion $\bar{\chi}=3.01, \mathrm{SD}=1.611)$.

Also, a total of 291 representing $51.1 \%$ of the respondents discredited the statement that request for construction of bridges by the populace has been catered for by the local government $\bar{\chi}=3.39$, SD $=1.433)$. However, this does not have absolute implication because there are pockets of respondents equating 35\% who agreed with this statement; while $19(3.3 \%)$ of the respondents did not react to the statement; and $61(10.7 \%)$ of the respondents were undecided. In this regards, citizens' requests for bridges have an average impact on social services to be delivered by the local government in Nigeria.

Respondents expressed their views on the sufficiency of motor-parks at their respective local government areas. About $97(17 \%)$ of the respondents strongly agreed and 197 (34.6\%) of the respondents agreed to the statement that there are enough motor parks that encourage the flow of goods and services to another part of the country. Meanwhile, 129 (22.6\%) of the respondents disagreed; and 85 representing $14.9 \%$ of the respondents strongly disagreed with this assertion $\bar{\chi}=3.20, \mathrm{SD}=1.260)$. This implies that there appears to be a considerable number of respondents who acknowledged the sufficiency of motor parks in the localities.

In addition, respondents were asked to either agree or disagree on the statement on whether grading of roads, especially in core rural areas, has increased the flow of farm products from farm settlements to the cities. In their responses, $120(21.1 \%)$ of the respondents strongly agreed to this assertion; and 209 (36.7\%) of the respondents ordinarily agreed. This becomes statistically denoted by the $\bar{\chi}=3.21, \mathrm{SD}=1.257$ ) which is above mid-point 3.0. Meanwhile, $131(23 \%)$ of the respondents disagreed with this assertion; and $74(13 \%)$ of the respondents strongly disagreed. This is an indication that local government has a considerable impact on the grading of roads across local communities in Southwestern Nigeria.

Also, 105 (18.4\%) of the respondents strongly agreed; and 139 (24.4\%) also neutrally agreed. However, 105 (18.4\%) strongly disagreed and 165 (28.4\%) of the respondents disagreed on the statement that the construction and maintenance of street lightings have a positive impact on social development in the local government. Though, about 42 (7.4\%) of the respondents 
remain indifferent to the assertion; while $14(2.5 \%)$ of the respondents did not react to this assertion. In this respect, this result showed relative level on both agreements $42.8 \%$ and disagreement $47.3 \%$ of the respondents respectively $\overline{(\chi}=2.81, \mathrm{SD}=1.699)$. This implies that local government has, but not to a remarkable extent, impact on construction and maintenance of street lightings within the period under study in the study area.

Also, it was categorically asserted for respondents to either agree or disagree on whether the inability to render quality service is evident by the number of poor quality of services, especially in primary education and road construction between 1999 and 2015. Reacting to this, about $131(23 \%)$ of the respondents strongly agreed and $252(44.2 \%)$ of the respondents agreed on the assertion. On aggregate, respondents on agreement level summed up to $67.2 \%$, more than those who were undecided $(9.5 \%)$; those who fell in the disagreement category $(20.5 \%)$; and about $2.8 \%$ of the respondents did not respond to this assertion $\overline{(\chi}=3.61, \mathrm{SD}=$ 1.192). It can therefore be hypothesised that local government has a significant impact on social services delivery in the study area between 1999 and 2015. Thus, the claim was further subjected to a hypothesis test using the correlation co-efficient analysis, denoted as the hypothesis of this study. To complement the data gathered through questionnaire administration, some key stakeholders were interviewed. Some of them agreed that the impact of local government has not been felt on road construction in recent years. They were also of the opinion that, in critical analysis of primary education in Nigeria, local government had made some impact in primary education by paying the salary of teachers directly or indirectly, building schools, providing instructional materials and providing other infrastructure needed, which had made the objective of primary education to be achieved in various state of the region.

In the areas of primary education, some stakeholders attested to the fact that the contributions of local government in sustaining primary education have been commendable and it has impacted the pupils positively. In the words of Ekiti State NUT Chairman, "primary education has been a fundamental right of every citizen in the state, and this service has been free to every pupil that cares to enroll in public schools." So also, the PTA/ CBSMC Chairman in Osun State stated that:

the basic knowledge and proper foundation that is needed for every pupil or ward, so as to inculcate permanent literacy into their destiny has been achieved due to the contributions of the three tiers of government in primary education particularly the contribution of local government. (Field survey, 2018).

In assessing the impact of the social service delivery, particularly on road construction by the local government the Ekiti State CDAs Chairman attested to the fact that:

the inability of local government due to lack of capacity to construct good road especially in rural areas and farm settlement had been a major clog for the free flow of goods and services from farm settlement or rural areas to the city or urban areas. (Field survey, 2018)

Other stakeholders interviewed also attested to this deficiency in the areas of the road 
network at the local level.

More so, other stakeholder interviewed attested to the fact that the contribution of local governments in sustaining primary education cannot be overemphasised, and that the impact of primary education on the citizens has been felt to be moderately okay in the region, though there are still a lot of expectation from the governments to the education sector for better result and more impacts. At the same time, most of the interviewee also agreed that local government perform their functions and contribute more to primary education between the years 1999 to 2007 than the recent times.

\section{Recommendations}

There is an urgent need for elements of good governance to be enshrined in the activities of JAAC. Though there were varied opinions on the existence of JAAC, some are asking for the scrapping of that committee while some are otherwise. Vis- $a$-vis the different opinions, there is an urgent need for the committee to imbibe the principles of good governance, which range from rule of law, proper participation, accountability, transparency, responsiveness, proper consensus orientation, equity and inclusiveness effectiveness and efficiency so as to enhance service delivery at the local level.

The committee should be more transparent and accountable in the sense that any project solely provided by local government should be clearly stated, the ones they are to jointly finance with the state should also be clearly stated, even to the awareness of the citizens, so as to know the tiers of government that is responsible for a particular project. The principles of fairness which say that justice must not only be done but must be seen to have been done. The activities and agreements reached by JAAC pertaining to the appropriation of funds to provide services should be well known to the populace to know who is to be held responsible or accountable. Appropriate participation, transparency, and accountability of this committee would help the citizens to know the activities and contributions of each tier of government to service delivery, and the necessary accolade would be given accordingly.

\section{Conclusion}

The study concluded that local government in Southwestern Nigeria had a momentous impact on the delivery of social service to the people at the grassroots with regards to both mandatory and concurrent function, especially in the areas of primary education and construction of roads, though, they had not been able to perform to expectation in their mandatory functions.

\section{References}

Adeosun, A. B. (2012). Nigeria@ 50: The Role of Good Governance and Effective Public Administration Towards Achieving Economic Growth and Stability in Fledgeling Democracy International Journal of Politics and Good Governance, 3(3.3), 0976-1195 Quarter III.

Adeyemi, O. (2013). Local Government and the Challenges of Service Delivery: The Nigeria Adeyemo, D. O. (2005). Local Government Autonomy in Nigeria: A Historical Perspective, 
Journal of Social Science, 10(2), 77-87.

Adeyeye, M. O. (2016). Governing the Localities: Lessons (UN) Learnt, 284 Series Inaugural Lecture Delivered at Oduduwa Hall, Obafemi Awolowo University Ile-Ife, Nigeria, on Tuesday, $22^{\text {nd }}$ March 2016.

Agba, A., \& Idu. (2013). Local Government and Social Service Delivery in Nigeria: A Content Analysis.Academic Journal of Interdisciplinary Studies, 2(2), 455-462. https://doi.org/10.5901/ajis.2013.v2n2p455

Ake, C. (1975). A Definition of Political Stability. Comparative Politics, 7(2), 271-283. https://doi.org/10.2307/421552

Almond, G., \& Powell, G. B. (1966). Comparative Politics: A Developmental Approach. Boston: Little, Brown \& Co.

Angahar, A. P. (2013). The Impact of Existing Inter-Governmental Financial Relation on Effective Service Delivery at the Grassroots in Nigeria. International Journal of Academic Research in accounting, Finance and Management Sciences, 3(1), 112-118.

Anikpo, M. (2006). Foundation of Social Science Research. Portharcourt: Uniport Press.

Boulding, K. (1962). The Boundaries of Social Policy, In Social Work, 12(1), 3-11.

Chazan, N. (1992). Liberalization, Governance and Political Space in Ghana, in Hyden, G and Bratton, M (eds), Governance and Politics in Africa, Boulder \& London: Lynne Rienner Publishers.

Coleman, J. (1965). Nigeria Background to Nationalism. Angeles. University of California.

Conable, B. B. (1997). Reflection on Africa, the priority of Six - year Africa in Economic Development" An Address Delivered by the President of the World Bank

Das, H. H., \& Choudhury, B. C. (2002). Introduction to Political Sociology. New Delhi: Vikas Publishing House PVT Ltd.

Dower, A. (2000). Good Governance: Guiding Principle for Implementation. Australia, Ministry for Foreign Affairs.

Experience. Journal of Sustainable Development in Africa, 1(7), 84-98.

FRN. (1999). Constitution of the Federal Republic of Nigeria 1999, Lagos: Federal Government Press.

Fukuyama, F. (2013). What Is Governance? CGD Working Paper 314. Washington, DC: Center for Global Development.

Galadima, H. S. (1998). Militarism and Governance in Nigeria', Journal of the Institute of Governance and Social Research, 1(1), 96-103.

Geol, S. L. (1981). Health Care Administration, New Delhi: Sterling Publishers Private Limited. 
Hope, K. R. (2005). Corruption and Development in Africa in K. R. Hope and B. C. Chikulo (eds) Op cit.

Maddick, H. (1963). Democracy, Decentralization \& Development: Asia Publishing House, Bombay.

Madhav, G. (2007). Report of the one man Comittee on Good Governance, July Human Right Watch (2007). "Election or "Selection"? Human Rights Abuse and Threats to Free and Fair Elections in Nigeria” http://hrw.org/backgrounder/africa/nigeria0407/index.ht.

Natufe, I. (2006). "Governance and politics in Nigeria" A lecture delivered at the staff and graduate seminar, department of political science and public administration, University of Benin on November 21.

Ninalowo, M. O. A. (2005). Antimonies of corruption and democratic governance In L. Olurode, \& S.O. Akinboye [eds], Democracy, good governance and corruption in Nigeria. Friedrich Ebert Siftung [FES].

Nnamani, \& Chilaka. (2012). Economic Reforms and Social Service Delivery in Nigeria 1999-2007: Issues and Options. Arabian Journal of Business and Management Review (OMAN Chapter), 2(4), 9-24.

Nwoba, M. O. E. (2015). An Evaluation of Social Services Delivered by Local Governments in Nigeria: A Study of Ebonyi State Local Governments Administration (1996-2012). Journal of Policy and Development Studies, 9(3), 142-152. https://doi.org/10.12816/0011172

Nyewusira, V. (2011). State-Local Government Relations In Rivers State, Nigeria (1999-2007) A Ph.D Thesis Submitted To The Department Of Public Administration And Local Government, Faculty Of Social Sciences, University Of Nigeria Nsukka

NZPC (New Zealand Productivity Commission). (2015). More effective social services Draft Report April 2015.

Odock, C. N. (2006). Democracy and Good Governance. Lagos: NOUN.

Olewe, B. N., \& Anga, J. S. (1994). Command Administration: The Police Perspective. Enugu: New Generation Books.

Onifade, D. (2011). Power Supply: We need the facts. The Guardian, Wednesday, 23February.

Robson, N. (1949). Local Government, in The Encyclopedia of the Social Sciences, 1(9), 1-23.

SSC. (2011). Better public services advisory group report. Retrieved 9 April 15 from www.ssc.govt.nz/sites/all/files/bps-report-nov2011_0.pd

The 1976 Local Government Reforms guidelines, Lagos, Federal Ministry of Information

Thomson, W. (2004). Delivering Service in Nigeria: A Roadmap. Office of Public Service Reform, United Kingdom. 
Titmus, R. M. (1968). Commitment of Welfare, Allen and Unwin, New York.

UNDP. (1997). Decentralized Governance Programme: Strengthening Capacity for People -Centred Development, Management Development and Governance Division, Bureau for Development Policy. Joint UNDP-Government of Germany Evaluation Working Paper of the UNDP Role in Decentralization and Local Governance October 1999.

Yaqub, O., \& Abubakar, S. O. (2005). Conceptualising good governance, corruption and democracy In L. Olurode \& S.O. Akinboye [eds], Democracy, good governance and corruption in Nigeria. Friedrich Ebert Shiftung [FES].

\section{Copyright Disclaimer}

Copyright for this article is retained by the author(s), with first publication rights granted to the journal.

This is an open-access article distributed under the terms and conditions of the Creative Commons Attribution license (http://creativecommons.org/licenses/by/4.0/). 